\title{
A Study of the Principle of Fair Balance in the Jurisprudence of the European Court of Human Rights
}

\begin{abstract}
Alastair Mowbray, Professor of Public Law, University of Nottingham: My thanks to Phillip Elam of Information Services, University of Nottingham for undertaking a literature search.
\end{abstract}

(C) A.R. Mowbray

This is a pre-copy-editing, author-produced PDF of an article accepted for publication in Human Rights Human Rights Law Review. 10(2), 289-317 (2010) following peer review. The definitive publisherauthenticated version is available online at: http://hrlr.oxfordjournals.org/cgi/reprint/ngq006?

ijkey=7TTp90LathXRapm\&keytype=ref .

\begin{abstract}
This study begins by examining the origins of the fair balance principle. There follows an analysis of the application of the principle across a range of rights and freedoms guaranteed by the European Convention. The functions performed by the fair balance principle, together with the factors assessed by the Court when utilising the principle are distilled from the case-law. Conclusions are drawn as to the relationship between the fair balance principle and the margin of appreciation doctrine.
\end{abstract}

The principle of fair balance ${ }^{1}$ is ubiquitous in the case-law of both the original and fulltime European Court of Human Rights (hereafter the Court). ${ }^{2}$ Indeed, according to the former, "...inherent in the whole of the Convention ${ }^{3}$ is a search for a fair balance

\footnotetext{
${ }^{1}$ It was so described by the Grand Chamber in Hutten-Czapsk $v$ Poland, Judgment of 19 June 2006, 45 EHRR 4, heading to para. 167.

${ }^{2}$ A search of the Court's HUDOC database produces $100+$ references to the principle: available from www.echr.coe.int.

${ }^{3}$ The European Convention on Human Rights.
} 
between the demands of the general interest of the community and the requirements of the protection of the individual's fundamental rights. ${ }^{\prime 4}$ A Grand Chamber of the current Court has explicitly endorsed that view. ${ }^{5}$ Yet some of the most esteemed commentators on the Convention have observed, "[h]owever, the very notion of fair balance is obscure and amenable to a varying margin of appreciation..." ${ }^{\prime 6}$ Therefore, we shall seek to discover the origins of, and functions performed, by this principle. That will involve examining the range of Articles under which it has been applied and the factors considered by the Court when utilising the principle. It will be important to ascertain what competing interests the Court identifies when undertaking the balancing process. Additionally, it will be illuminating to determine if there are links between the fair balance principle and other general concepts enshrined in the Court's jurisprudence.

\section{The Foundations of the Fair Balance Principle}

In the very earliest case-law the original Court found an implied principle of "just balance" within the Convention.

"The Court considers that the general aim set for themselves by the Contracting Parties through the medium of the European Convention on Human Rights, was to provide effective protection of fundamental human rights, and this, without doubt not only because of the historical context in which the Convention was concluded, but also of the social and technical developments in our age which offer to States considerable possibilities for regulating the exercise of these rights. The Convention therefore implies a just balance between the protection of the general interest of the Community and the respect due to fundamental human rights while attaching particular importance to the latter. ${ }^{\prime 7}$

${ }^{4}$ Soering $v$ UK, A.161 (1989), 11 EHRR 439, at para. 89.

${ }^{5}$ N. v UK, Judgment of 27 May 2008, 47 EHRR 39, at para. 44.

${ }^{6}$ P. van Dijk , F. van Hoof, A. van Rijn \& L. Zwaak (eds), Theory and Practice of the $E C H R, 4^{\text {th }}$ ed. (Antwerpen: Intersentia, 2006) p. 349.

${ }^{7}$ Case "Relating to Certain Aspects Of The Laws On The Use of Languages In Education In Belgium" v Belgium (Merits) A.6 (1968), 1 EHRR 252, generally referred to as the "Belgian Linguistic" case, at para. B.5. 
So the basis of the principle was not the text of the particular Articles being litigated, prohibition of discrimination ${ }^{8}$ in combination with the right to education ${ }^{9}$, but a basic requirement that member States achieve an appropriate equilibrium in safeguarding the well-being of their populations whilst protecting the fundamental rights of individuals against a background of rapid social, e.g. gender equality ${ }^{10}$, and technological, e.g. interception of communications ${ }^{11}$, evolution. However, Judge Terje Wold categorically opposed the approach of the Plenary Court's majority:

"And even worse is the interpretation by the majority that the Convention "implies a just balance between the protection of the general interest of the community and the respect due to fundamental human rights". I strongly disagree with this interpretation. In my opinion it carries the Court into the very middle of the internal political questions of each Member State, which it has never been the intention that the Court should deal with."12

Hence, we learn that judicial recognition of an implicit balancing principle in the Convention was controversial from its inception. We shall have to consider whether Judge Wold's fear that the application of the principle would encourage the Court to transgress beyond its jurisdiction into political decision-making has occurred when we have examined the later jurisprudence.

8 Article 14.

${ }^{9}$ Article 2 of Protocol No 1.

10 Such as married women choosing the surname they wished to be known by: Unal Tekeli v Turkey, Judgment of 16 November 2004, 42 EHRR 53.

${ }^{11}$ For the mass interception of voice and email communications: Liberty and Others $v$ UK, 1 July 2008, 48 EHRR 1.

${ }^{12}$ Supra n.7 Partly Dissenting Opinion of Judge Terje Wold at p. 101. 
The original Court later substituted the language of a "fair balance" for that of a "just balance". In Sporrong and Lonroth $v$ Sweden ${ }^{13}$ the applicant landowners had been subject to zonal expropriation permits and orders prohibiting construction on their land for many years. Eventually, the measures were rescinded when the local authority abandoned its planned developments. However, the applicants contended that the measures had interfered with their right to the peaceful enjoyment of their property ${ }^{14}$. The plenary Court held that:

"For the purposes of the latter provision, the Court must determine whether a fair balance was struck between the demands of the general interest of the community and the requirements of the protection of the individual's fundamental rights (see, mutatis mutandis, the judgment of 23 July 1968 in the "Belgian Linguistic" case, Series A no. 6, p. 32, par. 5). The search for this balance is inherent in the whole of the Convention and is also reflected in the structure of Article 1 (P1-1).

The Agent of the Government recognised the need for such a balance. At the hearing on" the morning of 23 February 1982, he pointed out that, under the Expropriation Act, an expropriation permit must not be issued if the public purpose in question can be achieved in a different way; when this is being assessed, full weight must be given both to the interests of the individual and to the public interest.

The Court has not overlooked this concern on the part of the legislature. Moreover, it finds it natural that, in an area as complex and difficult as that of the development of large cities, the Contracting States should enjoy a wide margin of appreciation in order to implement their town-planning policy. Nevertheless, the Court cannot fail to exercise its power of review and must determine whether the requisite balance was maintained in a manner consonant with the applicants' right to "the peaceful enjoyment of [their] possessions", within the meaning of the first sentence of Article 1 (P1-1)."15

A bare majority of the Court (ten votes to nine) went on to find a breach as the applicants had born an "excessive burden" in respect of the interferences with their

${ }^{13}$ A. 52 (1982), 5 EHRR 35.

${ }^{14}$ Article 1 of Protocol No 1.

${ }^{15}$ Supra n.13 at para. 69. 
properties (for up to twenty-five years) that "upset the fair balance which should be struck between the protection of the right of property and the requirements of the general interest". ${ }^{16}$

Frustratingly for us the Court did not explain why it had altered the language of the just/fair balance principle. But we did learn that the "structure of" Article 1 of Protocol No 1 (P1-1) provides a specific foundation for the fair balance principle. Whilst the text of P1-1 does not mention "fair balance" the Article expressly refers to allowing the deprivation of a person's possessions "in the public interest" and permitting States to control the use of property "in accordance with the general interest". Thereby requiring States, and the Court when faced with a complaint under P1-1, to reconcile the property owner's right to the peaceful enjoyment of his/her possessions and arguments that community interests must prevail over the former.

The full-time Court has followed its predecessor's approach and in Jahn and others $v$ Germany ${ }^{17}$, the Grand Chamber, after citing paragraph 69 of the judgment in Sporrong and Lonnroth, confirmed that the deprivation of a person's possessions under the second sentence of P1-1 was subject to the fair balance principle. An important aspect of this assessment required that "there must be a reasonable relationship of proportionality between the means employed and the aim sought to be realised by any measure depriving a person of his possessions..."18 The payment of appropriate compensation by the relevant State was a further key component in satisfying the fair balance principle.

${ }^{16}$ Ibid. at para. 73.

17 Judgment of 30 June 2005, 42 EHRR 49.

${ }^{18}$ Ibid. at para. 93. 
"Compensation terms under the relevant legislation are material to the assessment whether the contested measure respects the requisite fair balance and, notably, whether it imposes a disproportionate burden on the applicants. In this connection, the Court has already found that the taking of property without payment of an amount reasonably related to its value will normally constitute a disproportionate interference and a total lack of compensation can be considered justifiable under Article 1 of Protocol No. 1 only in exceptional circumstances..." ${ }^{19}$

The majority (eleven Judges) of the Grand Chamber, reversing the earlier unanimous Chamber judgment ${ }^{20}$, concluded that the legislative removal, by the Federal German Parliament, of the applicants' claims to agricultural land derived from an Act passed by the (former) "German Democratic Parliament" in 1990 did not breach P1-1. Even though the Federal legislation provided no compensation to the applicants the majority held that this was an exceptional situation. The applicants' claims were based upon a law enacted by a parliament that had not been democratically elected during the transition to a unified Germany.

\begin{abstract}
"Having regard to all the foregoing considerations and taking account, in particular, of the uncertainty of the legal position of heirs and the grounds of social justice relied on by the German authorities, the Court concludes that in the unique context of German reunification, the lack of any compensation does not upset the "fair balance" which has to be struck between the protection of property and the requirements of the general interest. ${ }^{21}$
\end{abstract}

Other Articles of the Convention have also been found to embody the fair balance principle by the full-time Court. For example, in Slivenko v Latvia ${ }^{22}$, the mother and daughter applicants complained of breaches of their rights to respect for their private lives and home, under Article 8, through their forced removal from Latvia as part of the agreed withdrawal of former UUSR military personnel and their families following the

${ }^{19}$ Ibid.at para. 94.

20 Judgment of 22 January 2004.

${ }^{21}$ Supra n.17 at para. 117.

22 Judgment of 9 October 2003, 39 EHRR 24. 
collapse of the USSR. The respondent government contended that the action taken against the daughter and granddaughter of a former USSR military officer based in Latvia was justified under Article $8(2)$ as being necessary to protect Latvian national security. The Grand Chamber held that:

"A measure interfering with rights guaranteed by Article 8(1) of the Convention can be regarded as being "necessary in a democratic society" if it has been taken in order to respond to a pressing social need and if the means employed are proportionate to the aims pursued. The national authorities enjoy a certain margin of appreciation in this matter. The Court's task consists in ascertaining whether the impugned measures struck a fair balance between the relevant interests, namely the individual's rights protected by the Convention on the one hand and the community's interests on the other." ${ }^{23}$

A majority of the Court (eleven votes) determined that the removal of the applicants did not strike a fair balance because they had been integrated into Latvian society and their relationship to a former USSR military officer did not pose a real danger to Latvian security. This was a significant judgment for its protection of the rights of individuals belonging to a minority in a newly emerging democracy.

From the above cases we have discovered that the principle of fair balance has ancient roots in the jurisprudence of the Court. Both the original and full-time Courts have traced the foundations of the principle to the nature of the Convention as a whole and to the requirements of specific Articles. Therefore, in the next section we shall examine how widespread the application of the principle is across the different rights and freedoms guaranteed by the Convention.

The range of Articles subject to the fair balance principle

${ }^{23}$ Ibid. at para. 113. 
The full-time Court has applied the fair balance principle when considering the right to life ${ }^{24}$ of foetuses. In Boso $v$ Italy ${ }^{25}$, the applicant complained, inter alia, that Italian legislation violated Article 2 in that it had permitted his wife to have an abortion against his wishes. The Court ruled that it was not required to determine if a foetus fell within the protection of the first sentence of Article $2^{26}$, but if a foetus was to have rights safeguarded by Article 2:

"the Court notes that the relevant Italian legislation authorises abortion within the first twelve weeks of a pregnancy if there is a risk to the woman's physical or mental health. Beyond that point, an abortion may be carried out only where continuation of the pregnancy or childbirth would put the woman's life at risk, or where it has been established that the child will be born with a condition of such gravity as to endanger the woman's physical or mental health. It follows that an abortion may be carried out to protect the woman's health.

In the Court's opinion, such provisions strike a fair balance between, on the one hand, the need to ensure protection of the foetus and, on the other, the woman's interests. Having regard to the conditions required for the termination of pregnancy and to the particular circumstances of the case, the Court does not find that the respondent State has gone beyond its discretion in such a sensitive area (see $H . v$. Norway, no. 17004/90, Commission decision of 19 May 1992, DR 73, p. 155)."27

Therefore, the Court determined that the applicant's complaint was manifestly illfounded.

Subsequently, the Grand Chamber in Vo $v$ France $^{28}$, after citing the fair balance extract from Boso, stated that:

"It follows from this recapitulation of the case-law that in the circumstances examined to date by the Convention institutions - that is, in the various laws on

${ }^{24}$ Article 2 of the ECHR.

${ }^{25}$ ECHR 2002- VII.

26 "Everyone's right to life shall be protected by law." (my emphasis).

${ }^{27}$ Supra n.25, The Law para. 1.

28 Judgment of 8 July 2004, 40 EHRR 12, and see A. Plomer, "A Foetal Right to Life? The Case of Vo v France" 5(2) Human Rights Law Review 311 (2005). 
abortion - the unborn child is not regarded as a "person" directly protected by Article 2 of the Convention and that if the unborn do have a "right" to "life", it is implicitly limited by the mother's rights and interests." 29

As there was still no consensus amongst the member States regarding the status of the embryo/foetus, the Grand Chamber concluded that it was neither desirable or possible to rule in the abstract whether an unborn child was a person for the purposes of Article 2 . However, the majority, fourteen votes to three, determined that French civil law provided sufficient protection for the applicant's deceased six-month-old foetus in respect of the medical negligence that had necessitated the unwanted termination of the applicant's pregnancy. Therefore, no breach of Article 2 had occurred.

From the above cases we learn that even the most basic of all Convention rights can be subject to a fair balance analysis. Given the potential conflict between the interests of a pregnant woman and her unborn foetus/child the Court has assessed whether domestic legislation authorising abortions has achieved a fair balance between those interests. Furthermore, against the background of the strong religious, ethical and social values offering competing views as to how this balance should be drawn in different States the Court has been extremely circumspect in defining the precise rights of the unborn.

The application of the fair balance principle to Article 3 of the Convention has caused controversy amongst both the member States and the judges of the Court. As the Article contains no express limitations the original Court refused to permit a member State to balance the alleged threat to its national security posed by the continued presence of a foreign national on its territory against the risks that person would suffer

${ }^{29}$ Ibid at para. 80. 
serious mal-treatment if returned to his home State in Chahal $v U K^{30}$. The applicant, an Indian national who had been permitted to remain in the UK after entering illegally, was detained pending deportation on national security grounds (he was believed to be linked to Sikh terrorism). He contended that he would face a real risk of treatment violating Article 3 if returned to India due to his notoriety and the violence connected to events in the Punjab. Before the Court, the British government argued that Chahal's alleged threat to British national security should be taken into account when evaluating if Article 3 would be breached if he was to be deported. The Court held that:

"79. Article 3 enshrines one of the most fundamental values of a democratic society... The Court is well aware of the immense difficulties faced by States in modern times in protecting their communities from terrorist violence. However, even in these circumstances, the Convention prohibits in absolute terms torture or inhuman or degrading treatment or punishment, irrespective of the victim's conduct. Unlike most of the substantive clauses of the Convention and of Protocols Nos 1 and 4, Article 3 make no provision for exceptions and no derogation from it is permissible under Article 15 even in the event of a public emergency threatening the life of the nation...

80. The prohibition provided by Article 3 against ill-treatment is equally absolute in expulsion cases. Thus, whenever substantial grounds have been shown for believing that an individual would face a real risk of being subjected to treatment contrary to Article 3 if removed to another State, the responsibility of the Contracting State to safeguard him or her against such treatment is engaged in the event of expulsion... In these circumstances, the activities of the individual in question, however undesirable or dangerous, cannot be a material consideration..." ${ }^{31}$

Applying this approach a majority of the Court (twelve votes to seven) concluded that the UK would breach Article 3 if the applicant was to be deported.

In the post $9 / 11$ era British legislative attempts to comply with Chahal whilst also protecting the UK population from resident foreign nationals who were alleged to have

30 (1997) 23 EHRR 413.

${ }^{31}$ Ibid. paras 79-80. 
terrorist links generated considerable national ${ }^{32}$ and Strasbourg $^{33}$ litigation. Other member States faced similar challenges and the full-time Court was asked to reconsider its Chahal approach in Saadi $v$ Italy ${ }^{34}$. The Tunisian applicant had been convicted in Italy of criminal conspiracy in 2005. The criminal court order his deportation after he had served his prison sentence. He was also convicted by a military court in Tunisia, whilst detained in Italy, of membership of a terrorist organisation and sentenced to twenty years' imprisonment. After his release in Italy the Minister of the Interior, exercising anti-terrorism powers, ordered the applicant's deportation to Tunisia. The applicant claimed, at Strasbourg, that he faced a real risk of serious mal-treatment if he was to be deported. The British government intervened in the Grand Chamber proceedings ${ }^{35}$ arguing that the rigid application of Chahal "had caused many difficulties for the Contracting States by preventing them in practice from enforcing expulsion measures." 36 The government considered that Chahal was contrary to the intentions of the framers of the Convention; and that the Court should now alter and clarify its approach to, inter alia, allow the threat posed by the foreign national to the host member State to be examined. According to the government the new test ought to take "into consideration all the particular circumstances of each case and weigh the rights secured to the applicant by Article 3 of the Convention against those secured to all other members of

32 e.g. A. v Home Secretary [2004] UKHL 56 and Home Secretary v JJ [2007] UKHL 45.

${ }^{33}$ e.g. A. and others $v$ UK, Judgment of 19 February 2009, 49 EHRR 29.

34 Judgment of 28 February 2008, see also D. Moeckli, "Saadi v Italy: The Rules of the Game Have Not Changed" 8(3) Human Rights Law Review 534 (2008).

35 Under Article 36(2) of the ECHR.

${ }^{36}$ Supra n.34 at para. 117. 
the community by Article $2 .{ }^{\prime \prime 37}$ The Italian government also supported this proposal. The unanimous Grand Chamber noted:

"first of all that States face immense difficulties in modern times in protecting their communities from terrorist violence... It cannot therefore underestimate the scale of the danger of terrorism today and the threat it presents to the community. That must not, however, call into question the absolute nature of Article 3.

138. Accordingly, the Court cannot accept the argument of the United Kingdom Government, supported by the respondent Government, that a distinction must be drawn under Article 3 between treatment inflicted directly by a signatory State and treatment that might be inflicted by the authorities of another State, and that protection against this latter form of ill-treatment should be weighed against the interests of the community as a whole (see paragraphs 120 and 122 above). Since protection against the treatment prohibited by Article 3 is absolute, that provision imposes an obligation not to extradite or expel any person who, in the receiving country, would run the real risk of being subjected to such treatment. As the Court has repeatedly held, there can be no derogation from that rule (see the case-law cited in paragraph 130 above). It must therefore reaffirm the principle stated in the Chahal judgment (cited above, § 81) that it is not possible to weigh the risk of illtreatment against the reasons put forward for the expulsion in order to determine whether the responsibility of a State is engaged under Article 3, even where such treatment is inflicted by another State. In that connection, the conduct of the person concerned, however undesirable or dangerous, cannot be taken into account..." ${ }^{\prime 38}$

The Grand Chamber concluded that, having regard to reports of NGOs and the US State Department, the applicant had established substantial grounds for believing that if he was to be deported to Tunisia he would face a real risk of mal-treatment violating Article 3. No adequate diplomatic assurances of safeguards to protect the applicant had been given by Tunisia, therefore if Italy was to deport him to that country it would breach Article 3.

So despite the increased risks that member States face from international terrorism the full-time Court has continued its predecessor's refusal to countenance the application of a balancing test to the deportation/extradition of suspected terrorists and their associates. In maintaining its Chahal approach the Grand Chamber in Saadi

${ }^{37}$ Ibid. at para. 122.

${ }^{38}$ Ibid. at paras 137-138. 
observed that the Committee of Ministers' (reflecting the political will of the member States) had adopted Guidelines ${ }^{39}$ affirming the absolute prohibition of Article 3 maltreatment in the fight against terrorism. ${ }^{40}$ However, indications that a number of these States had co-operated with the Bush administration's "extraordinary rendition" programme suggests that actual behaviour did not necessarily accord with the member States' declarations or Convention obligations. ${ }^{41}$

Yet in the context of deportations of foreigners suffering from serious illnesses the full-time Court has applied the fair balance principle. In $D . v U K^{42}$ the original Court found that it would amount to inhuman treatment for the UK to deport a person in the terminal stages of AIDS to his home State, St Kitts, where he had no-one to care for him and expensive drugs were not available to him. Subsequently other member States faced similar health related challenges to their deportation decisions at Strasbourg. A Grand Chamber reconsidered the issue in $N . v U K^{43}$, where the applicant was a Ugandan national who entered the UK in 1998. She was seriously ill and on admision to hospital was diagnosed as being HIV positive. A little later she developed two AIDS defining illnesses. She was given extensive antiretroviral treatments and her condition stabilised. Her claim for asylum was rejected in 2001, but she challenged her deportation arguing, on the basis of $D . v U K$, that it would violate Article 3 as the necessary drugs for her

${ }^{39}$ On 11 July 2002: $804^{\text {th }}$ meeting of the Ministers' Deputies.

${ }^{40}$ Supra n. 34 at para. 138.

41 See, A. Mowbray, Cases \& Materials on the ECHR $2^{\text {nd }}$ ed, (Oxford: OUP, 2007) at pp.253-255. On 21 August 2009, Dick Marty (the rapporteur of the Council of Europe's Parliamentary Assembly on secret detentions reported that his sources seemed to confirm that Lithuania, as well as Poland and Romania, had hosted a secret CIA prison.

42 (1997) 24 EHRR 423.

43 Judgment of 27 May 2008, 47 EHRR 39. 
continued treatment were in limited supply and expensive in Uganda. Eventually, the House of Lords rejected her appeal noting that it was doubtful if the member States of the Convention had intended it to apply in a manner requiring them to provide continuing medical care to the many persons in a similar predicament to the applicant. Before the Grand Chamber the government submitted that Article 3 only applied to deportations being challenged on medical grounds in exceptional circumstances and here the applicant was not in the terminal stages of her illness as $D$. had been. The Grand Chamber held that:

\begin{abstract}
"Although many of the rights it contains have implications of a social or economic nature, the Convention is essentially directed at the protection of civil and political rights (Airey v. Ireland, judgment of 9 October 1979, Series A no. 32, § 26). Furthermore, inherent in the whole of the Convention is a search for a fair balance between the demands of the general interest of the community and the requirements of the protection of the individual's fundamental rights (see Soering $v$. the United Kingdom, judgment of 7 July 1989, Series A no. 161, § 89). Advances in medical science, together with social and economic differences between countries, entail that the level of treatment available in the Contracting State and the country of origin may vary considerably. While it is necessary, given the fundamental importance of Article 3 in the Convention system, for the Court to retain a degree of flexibility to prevent expulsion in very exceptional cases, Article 3 does not place an obligation on the Contracting State to alleviate such disparities through the provision of free and unlimited health care to all aliens without a right to stay within its jurisdiction. A finding to the contrary would place too great a burden on the Contracting States. $2^{44}$
\end{abstract}

A majority (fourteen votes to three) concluded that as the applicant was not critically ill at that time her case could be distinguished from $D$. and there would be no breach of Article 3 if she was to be deported back to Uganda. The dissentients "strongly disagreed" with the majority's application of the fair balance principle to Article 3.

"Even though certain "proportionalist errings", severely criticised in legal writings, existed at one time, particularly in the case-law of the old Commission ${ }^{45}$, the

${ }^{44}$ Ibid. at para. 44.

45 (original footnote) S. van Drooghenbroeck, La proportionnalité dans le droit de la Convention européenne des droits de l'homme. Prendre l'idée simple au sérieux, (Brussels : Bruylant, Publications des Facultés universitaires Saint-Louis, 2001), pp. 125 et $\mathrm{s}$. 
balancing exercise in the context of Article 3 was clearly rejected by the Court in its recent Saadi v. Italy judgment of 28 February $2008^{46}$, confirming the Chahal judgment of 15 November $1996^{47} \ldots{ }^{\prime 48}$

We can hypothesize that the Grand Chamber in $N$. was willing to apply the fair balance principle to Article 3 due to the substance of the applicant's claim, which in effect was to be allowed to remain in the UK to receive ongoing medical care, as it involved difficult issues of public expenditure. Furthermore, the provision of health care is not a right that is expressly contained in the Convention ${ }^{49}$, therefore States may legitimately claim the need to balance the allocation of public resources and the economic claims of individuals. As the Court noted in $N$. :

"The United Kingdom authorities have provided the applicant with medical and social assistance at public expense during the nine-year period it has taken for her asylum application and claims under Article 3 and 8 of the Convention to be determined by the domestic courts and this Court. However, this does not in itself entail a duty on the part of the respondent State to continue to provide for her. ${ }^{\prime 50}$

The Court has also expressed apparently divergent views on the application of the fair balance principle to Article 5(1), the right to liberty and security. In $A$. and others $v$ $U K^{51}$, eleven foreign nationals who had been detained under the Anti-Terrorism, Crime

${ }^{46}$ (original footnote) Saadi v. Italy [GC], no. 37201/06, 28 February 2008.

47 (original footnote) Chahal v. the United Kingdom, judgment of 15 November 1996, Reports of Judgments and Decisions 1996-V.

${ }^{48}$ Joint Dissenting Opinion of Judges Tulkens, Bonello and Spielmann at para. 7.

49 The provision of some medical services may be derived from implied positive obligations arising under the Convention see, A. Mowbray, The Development of Positive Obligations under the ECHR by the ECtHR, (Oxford: Hart, 2004) at p.22.

50 Supra n.43 at para. 49.

${ }^{51}$ Supra n.33. 
and Security Act 2001, as the Home Secretary suspected them of being international terrorists and a risk to British national security but who (following Chahal) could not be deported back to their home States, challenged the lawfulness of their treatment under the Convention. The, unanimous Grand Chamber, held that

"The Court does not accept the Government's argument that Article $5 \S 1$ permits a balance to be struck between the individual's right to liberty and the State's interest in protecting its population from terrorist threat. This argument is inconsistent not only with the Court's jurisprudence under sub-paragraph (f) but also with the principle that paragraphs (a) to (f) amount to an exhaustive list of exceptions and that only a narrow interpretation of these exceptions is compatible with the aims of Article 5. If detention does not fit within the confines of the paragraphs as interpreted by the Court, it cannot be made to fit by an appeal to the need to balance the interests of the State against those of the detainee. ${ }^{\prime 52}$

Whilst not explicitly referring to a fair balance the Grand Chamber's language replicates the essence of the principle. The Court agreed with the House of Lords ${ }^{53}$ that the derogation measures taken against the applicants were disproportionate, as they only applied to suspected terrorists who were foreign nationals, consequently Article 5(1) had been breached in respect of those applicants who had not voluntarily left the UK. Yet, in the earlier Ocalan $v$ Turkey ${ }^{54}$ judgment another Grand Chamber of the full-time Court had stated that:

"Inherent in the whole of the Convention is a search for a fair balance between the
demands of the general interest of the community and the requirements of the
protection of the individual's fundamental rights. As movement about the world
becomes easier and crime takes on a larger international dimension, it is
increasingly in the interest of all nations that suspected offenders who flee abroad
should be brought to justice. Conversely, the establishment of safe havens for

52 Ibid. at para. 171.

${ }^{53}$ Supra n. 32.

54 Judgment of 12 May 2005, 41 EHRR 45. 
fugitives would not only result in danger for the State obliged to harbour the protected person but also tend to undermine the foundations of extradition..."

The Grand Chamber then went on to determine that the highly controversial arrest of the applicant, leader of a terrorist organisation, by Turkish officials at Nairobi airport did not violate Article 5(1). Although the respondent States conduct was of different forms in these cases it seems difficult to reconcile the blanket rejection of the application of the elements of the fair balance principle to Article 5(1), including its use to interpret the scope of the enumerated exceptions, in $A$. and others with its express invocation by the Grand Chamber in Ocalan.

The original Court in its plenary judgment concerning Article 5 in Brogan and others $v U K^{56}$ acknowledged the need for a "proper balance" in the response to terrorism by member States.

"The Court, having taken notice of the growth of terrorism in modern society, has already recognised the need, inherent in the Convention system, for a proper balance between the defence of the institutions of democracy in the common interest and the protection of individual rights..." ${ }^{15}$

When analysing whether the applicants, suspected terrorists, had been brought before a judge/released from detention promptly, as required by Article 5(3), the majority (twelve votes to seven) concluded that whilst the terrorist context justified the authorities detaining the applicants longer than other types of suspects none of the applicants had been released promptly. However, Judge Martens in his dissent expressed the view that:

${ }^{55}$ Ibid. at para. 88.

${ }^{56}$ A. 145 (1988). 11 EHRR 117.

${ }^{57}$ Ibid. at para. 48. 
"Striking a fair balance between the interests of the community that suffers from terrorism and those of the individual is particularly difficult and national authorities, who from long and painful experience have acquired a far better insight into the requirements of effectively combating terrorism and of protecting their citizens than an international judge can ever hope to acquire from print, are in principle in a better position to do so than that judge!"58

Given the scale of the terrorism concerning Northern Ireland, the democratic tradition of the UK and the annual reviews of the anti-terrorism legislation he concluded that the maximum length of police detention authorised (seven days) did not breach Article 5(3). So even when the Court has recognised the need to apply the fair balance principle to Article 5 complaints how the balance is to be assessed according to the particular facts of the case may be a matter of dispute amongst the judges.

The full-time Court has applied the fair balance principle to Article 6 (the right to a fair trial). In Nikitin $v$ Russia ${ }^{59}$, the applicant complained that a few weeks after his acquittal of serious charges, including treason, the Procurator-General requested the Presidium of the Supreme Court to review the case in supervisory proceedings. The Supreme Court dismissed the request as the defects in the trial proceedings were the fault of the prosecution. In his complaint to Strasbourg the applicant, inter alia, contended that the undertaking of the supervisory review after his acquittal amounted to a breach of Article 6(1). The unanimous Court reasoned that as Article 4(2) of Protocol No 7 expressly permitted the reopening of criminal proceedings in defined circumstances, e.g. where evidence of new facts has emerged, and the Committee of Ministers had asked States to establish mechanisms to allow the reopening of criminal cases where the Court had found a breach of Article 6 in the original domestic

${ }^{58}$ Ibid. Dissenting Opinion of Judge Martens at para. 12.

59 Judgment of 20 July 2004, 41 EHRR 10. 
proceedings, the possibility of re-opening a criminal case was not per se incompatible with Article 6.

\begin{abstract}
"However, certain special circumstances of the case may reveal that the actual manner in which it was used impaired the very essence of a fair trial. In particular, the Court has to assess whether, in a given case, the power to launch and conduct a supervisory review was exercised by the authorities so as to strike, to the maximum extent possible, a fair balance between the interests of the individual and the need to ensure the effectiveness of the system of criminal justice. ${ }^{\prime 60}$
\end{abstract}

Here the Presidium had only examined the preliminary issue of whether to reopen the case against the applicant (if it had decided to authorise a reopening then new adversarial proceedings would have been held), therefore the Court concluded that the Presidium had not failed "to strike a fair balance between the interests of the applicant and the need to ensure the proper administration of justice. ${ }^{\prime 61}$ Hence the Court was utilising the fair balance principle to check that acquitted defendants did not suffer undue burdens whilst criminal justice systems maintained the opportunity to exceptionally reopen proceedings in order to correct injustices.

The fair balance principle has been utilised extensively by the Court when applying Article 8 (right to respect for private and family life) across a diverse range of situations. Examples include the need for States to provide full legal recognition of the new personalities of post-operative transsexuals elaborated by the Grand Chamber in Christine Goodwin $v U K^{62}$, where it was held that:

"...the respondent Government can no longer claim that the matter falls within their margin of appreciation, save as regards the appropriate means of achieving recognition of the right protected under the Convention. Since there are no significant factors of public interest to weigh against the interest of this individual

${ }^{60}$ Ibid. at para. 57.

${ }^{61}$ Ibid. at para 59.

62 Judgment of 11 July 2002, 35 EHRR 18. 
applicant in obtaining legal recognition of her gender re-assignment, it reaches the conclusion that the fair balance that is inherent in the Convention now tilts decisively in favour of the applicant. There has, accordingly, been a failure to respect her right to private life in breach of Article 8 of the Convention. ${ }^{\prime 63}$

Through to assessing whether States have provided adequate protection to homes from serious pollution as in the Heathrow night flights case of Hatton and others $v U K^{64}$. The Grand Chamber, by twelve votes to five, found no breach of Article 8 due to the detailed controls over night flights using the airport.

"In these circumstances the Court does not find that, in substance, the authorities overstepped their margin of appreciation by failing to strike a fair balance between the right of the individuals affected by those regulations to respect for their private life and home, and the conflicting interests of others and of the community as a whole, nor does it find that there have been fundamental procedural flaws in the preparation of the 1993 regulations on limitations for night flights. ${ }^{\prime 65}$

We should not be surprised at the variety of Article 8 cases invoking the fair balance principle given the breadth of the rights protected by this provision ${ }^{66}$. Furthermore, as we have seen already in Slivenko ${ }^{67}$, the structure of Article 8 enables States to argue that interferences with Article 8(1) rights are justified for legitimate community interests under Article $8(2)$ and this encourages the Court to apply the fair balance principle to assess the disputed equilibriums reached by States.

Under Article 9 (freedom of thought, conscience and religion) the full-time Court has applied the fair balance principle to evaluate whether public authorities have

${ }^{63}$ Ibid. at para. 93.

${ }^{64}$ Judgment of 8 July 2003, 37 EHRR 28.

${ }^{65}$ Ibid. at para. 129.

${ }^{66}$ See supra n.41 at Ch. 10.

${ }^{67}$ Supra n.22. 
unjustifiably intervened in the internal disputes of a religious organisation. The complex background to Holy Synod of the Bulgarian Orthodox Church (Metropolitan Inokentiy) v. Bulgaria ${ }^{68}$, concerned a split in the Bulgarian Christian Orthodox Church after the collapse of the Communist regime in 1989. The applicants established a new leadership, known as the alternative Synod, as they believed that the Patriarch who had been appointed under the Communists had been proclaimed in breach of the Church's traditional canons. In subsequent years the rival groups within the Church were linked with different political parties. A new government, in 2002, announced its support for the Patriarch and legislation was passed which denied access to church assets to those who split from such an organisation. Following a complaint by the Patriarch, public prosecutors issued orders for the removal of the applicants and their supporters from Church buildings, resulting in over 50 evictions by the police. The applicants brought an action at Strasbourg alleging, inter alia, a breach of Article 9 as the authorities had arbitrarily intervened in the dispute within the Church favouring the established Patriarch. The unanimous Court ruled that:

"The issue before the Court is, however, whether the concrete measures chosen by the authorities could be accepted as lawful and necessary in a democratic society and, in particular, whether those measures were proportionate and struck a fair balance between the declared aim of securing legality and the rights of the individuals and organisations concerned. ${ }^{\prime 69}$

In the judgment of the Court the extensive intervention by the government in the affairs of the Church with the objective of forcing the membership to support the leadership endorsed by the authorities was disproportionate and violated the applicants' rights under Article 9. It is a well-established aspect of the Court's Article 9 jurisprudence that public authorities must not seek to impose their preferred leaderships on divided

68 Judgment of 22 January 2009.

${ }^{69}$ Ibid. at para. 132. 
religious organisations. Indeed, two earlier judgments had found different Bulgarian governments to have unlawfully interfered in analogous disputes within the Bulgarian Muslim community. ${ }^{70}$

Both the original and full-time Courts have applied the fair balance principle in cases involving Article 10 (freedom of expression). In Vogt $v$ Germany ${ }^{71}$, the issue for the former was whether the dismissal of a school teacher, who had the status of a civil servant, because she engaged in electoral activities on behalf of the Communist Party violated her right to political expression. The German courts had determined that civil servants who actively supported the Communist Party were in breach of their duty of loyalty to the state, due to their endorsement of the Party's anti-constitutional objectives. The Court held that:

"Although it is legitimate for a State to impose on civil servants, on account of their status, a duty of discretion, civil servants are individuals and, as such, qualify for the protection of Article 10 of the Convention. It therefore falls to the Court, having regard to the circumstances of each case, to determine whether a fair balance has been struck between the fundamental right of the individual to freedom of expression and the legitimate interest of a democratic State in ensuring that its civil service properly furthers the purposes enumerated in Article 10 para. 2. In carrying out this review, the Court will bear in mind that whenever civil servants' right to freedom of expression is in issue the "duties and responsibilities" referred to in Article 10 para. 2 assume a special significance, which justifies leaving to the national authorities a certain margin of appreciation in determining whether the impugned interference is proportionate to the above aim. ${ }^{172}$

By a bare majority of one the Grand Chamber concluded that the dismissal of the applicant was a disproportionate measure given her good teaching record.

70 See Hasan and Chaush v Bulgaria, (2002) 34 EHRR 55 and Supreme Holy Council of the Muslim Community v Bulgaria, Judgment of 16 December 2004, 41 EHRR 3.

${ }^{71}$ A.323 (1995), 21 EHRR 53.

72 Ibid. at para. 53. 
In Appleby and others $v U K^{73}$, the full-time Court was confronted with the argument that the applicants' right to political expression had been infringed as domestic law accorded the private owners of a town centre shopping-complex power to deny the applicants permission to campaign for public support, on the future of a local park, in the complex. The Court considered that the applicants' complaint involved the question whether the respondent State was in breach of its positive obligation to protect freedom of expression.

"In determining whether or not a positive obligation exists, regard must be had to the fair balance that has to be struck between the general interest of the community and the interests of the individual, the search for which is inherent throughout the Convention. The scope of this obligation will inevitably vary, having regard to the diversity of situations obtaining in Contracting States and the choices which must be made in terms of priorities and resources. Nor must such an obligation be interpreted in such a way as to impose an impossible or disproportionate burden on the authorities. ${ }^{\prime 74}$

Given that the applicants had alternative methods of campaigning, such as visiting residents' homes or via the local media, a majority of the Court (six votes to one) found that the UK had not failed to protect the applicants' freedom of expression.

As Article 10 has a similar structure to that of Article 8 we should not be surprised to have discovered that the Court has also applied the fair balance principle when evaluating if particular applicants' freedom of expression had been violated. Likewise the Grand Chamber in Chassagnou and others $v$ France ${ }^{75}$, had regard to the fair balance principle when assessing if the applicants' negative right to freedom of association under Article 11 had been breached. French legislation obliged the owners of small pieces of rural land to join local hunters' associations and permit members to hunt on their land.

73 Judgment of 6 May 2003, 37 EHRR 38.

${ }^{74}$ Ibid. at para. 40.

75 Judgment of 29 April 1999, 29 EHRR 615. 
The applicants had ethical objections to hunting, but the government claimed that the legislation could be justified under Article 11(2) as being necessary to enable wide public participation in hunting. The Grand Chamber considered that:

"To compel a person by law to join an association such that it is fundamentally contrary to his own convictions to be a member of it, and to oblige him, on account of his membership of that association, to transfer his rights over the land he owns so that the association in question can attain objectives of which he disapproves, goes beyond what is necessary to ensure that a fair balance is struck between conflicting interests and cannot be considered proportionate to the aim pursued. ${ }^{\prime 76}$

Therefore, a large majority, twelve vote to five, concluded that the applicants had suffered a breach of Article 11.

We have already examined the origins of the Court's application of the fair balance principle in the context of complaints alleging discriminatory treatment violating Article 14 and a connected substantive Convention right. ${ }^{77}$ In more recent times the Court has stated that:

"In other words, the notion of discrimination includes in general cases where a person or group is treated, without proper justification, less favourably than another, even though the more favourable treatment is not called for by the Convention (Abdulaziz, Cabales and Balkandali v. the United Kingdom, judgment of 28 May 1985, Series A no. 94, p. 39, § 82). Article 14 does not prohibit distinctions in treatment which are founded on an objective assessment of essentially different factual circumstances and which, being based on the public interest, strike a fair balance between the protection of the interests of the community and respect for the rights and freedoms safeguarded by the Convention (see, among other authorities, G.M.B. and K.M. v. Switzerland (Dec.), no. 36797/97, 27 September 2001)..$^{178}$

${ }^{76}$ Ibid. at para. 117.

${ }^{77}$ In the Belgian Linguistic case supra n.7.

${ }^{78}$ Zarb Adami v Malta, Judgment of 20 June 2006, 44 EHRR 3, at para. 73. 
The majority, six votes to one, found that the respondent State had not provided a satisfactory justification as to why men were much more likely to be obliged to undertake jury service than women. Hence, the male applicant had suffered a breach of Article 14 in association with Article 4(3)(d) (prohibition of slavery and forced labour). Additionally, our previous analysis of the foundations of the fair balance principle has disclosed the Court's regular utilisation of the principle when determining if there has been an infringement of the protection of property $(\mathrm{P} 1-1) .^{79}$

Overall we have discovered that the Court has indeed applied the fair balance principle across the vast majority of rights safeguarded by the Convention, thereby confirming the accuracy of its Soering mantra ${ }^{80}$. Where it has not been applied, for example in respect of Article 12, this may be due to the limited amount of case law under those Articles. Perhaps it is to be expected that the Court's utilisation of the principle has been most divisive in respect of the unqualified Article 3. However, as $N . v$ $U K^{81}$ disclosed, at least where the complaint has strong socio-economic overtones, the fair balance principle can be applied even in respect of the most absolute right guaranteed by the Convention. ${ }^{82}$ Conversely, where Articles expressly include limitation

${ }^{79}$ Supra n.13 and 17.

${ }^{80}$ Supra n.4.

${ }^{81}$ Supra n.43.

82 For a firm argument that the Convention does not generally protect economic and social rights see, C. Warbrick, "Economic and Social Interests and the ECHR" in Economic, Social and Cultural Rights in Action ed. By M.A. Baderin and R. McCorquodale (Oxford: OUP, 2007). A. Nolan has found a lack of conceptual clarity in the Court's attitude towards the protection of economic and social rights: "Addressing Economic and Social Rights Violations by Non-state Actors through the Role of the State: A Comparison of Regional Approaches to the "Obligation to Protect"'", 9(2) Human Rights Law Review 225 (2009). 
clauses authorising States to interfere with protected rights in order to promote community interests the Court has frequently resorted to the fair balance principle. ${ }^{83}$

\section{Functions performed by the fair balance principle}

We can discern from the Court's jurisprudence at least two discrete functions being performed by the fair balance principle. First the principle enables the Court to assess the proportionality of the respondent State's conduct. ${ }^{84}$ Several commentators have identified the fair balance principle as the basis for the Court undertaking a proportionality analysis. Yutaka Arai-Takahashi has observed that:

"It must be recalled that under the Convention, there exist two types of proportionality evaluation emphasised by the Strasbourg organs. Firstly, they have asserted that a "fair balance" must be struck between the right of individual applicants and the general interests of the public. ...The second meaning of proportionality is a modified and more specific version of the first and defined as a reasonable relationship between the means employed, including their severity and duration, and the public objective to be sought." ${ }^{\prime 85}$

Also, D.J.Harris et al. have expressed the view that in respect of the Court's assessment of whether a fair balance has been attained, "[t]he achievement of such a balance necessarily requires an approach based, inter alia, upon considerations of proportionality. ${ }^{186}$

${ }^{83}$ For example in complaints based upon Article 8.

${ }^{84}$ On the topic of proportionality see, J. McBride, "Proportionality and the European Convention on Human Rights" in E. Ellis (ed), The Principle of Proportionality in the Laws of Europe (Oxford: Hart, 1999).

85 Y. Arai-Takahashi, The Margin of Appreciation Doctrine and the Principle of Proportionality in the Jurisprudence of the ECHR, (Antwerp: Intersentia, 2002) at p. 193.

${ }^{86}$ D.J. Harris, M.O'Boyle, E.P. Bates \& C.M. Buckley, Law of the ECHR $2^{\text {nd }}$ ed., (Oxford: OUP, 2009) at p. 10. 
A classic example of the Court analysing the proportionality of a State's interference with an applicant's Convention rights as an aspect of determining if a fair balance had been achieved was Hutten-Czapska $v$ Poland ${ }^{87}$. The applicant complained to the Court about the limitations, imposed by Polish legislation, on her ability to increase the rents payable by her tenants and restrictions on her right to terminate their tenancies. The government sought to justify the measures as being necessary to deal with the severe housing problems occurring during the transition from a communist to a free-market society. The Grand Chamber classified the applicant's complaint as falling within the second paragraph of Article 1 of Protocol No 1 (control of the use of a person's property in accordance with the general interest). To assess whether a breach had occurred the Grand Chamber held that:

"Not only must an interference with the right of property pursue, on the facts as well as in principle, a "legitimate aim" in the "general interest", but there must also be a reasonable relation of proportionality between the means employed and the aim sought to be realised by any measures applied by the State, including measures designed to control the use of the individual's property. That requirement is expressed by the notion of a "fair balance" that must be struck between the demands of the general interest of the community and the requirements of the protection of the individual's fundamental rights.

The concern to achieve this balance is reflected in the structure of Article 1 of Protocol No. 1 as a whole. In each case involving an alleged violation of that Article the Court must therefore ascertain whether by reason of the State's interference the person concerned had to bear a disproportionate and excessive burden..." 88

Unanimously, the Grand Chamber found that the Polish legislation pursued the legitimate aim of seeking to deal with the chronic shortage of homes. But:

"...the Polish State, which inherited from the communist regime the acute shortage of flats available for lease at an affordable level of rent, had to balance the exceptionally difficult and socially sensitive issues involved in reconciling the conflicting interests of landlords and tenants. It had, on the one hand, to secure the protection of the property rights of the former and, on the other, to respect the

${ }^{87}$ Supra n. 1.

${ }^{88}$ Ibid. at para. 167. 
social rights of the latter, often vulnerable individuals. Nevertheless, the legitimate interests of the community in such situations call for a fair distribution of the social and financial burden involved in the transformation and reform of the country's housing supply. This burden cannot, as in the present case, be placed on one particular social group, however important the interests of the other group or the community as a whole.

In the light of the foregoing, and having regard to the effects of the operation of the rent-control legislation during the whole period under consideration on the rights of the applicant and other persons in a similar situation, the Court considers that the Polish State has failed to strike the requisite fair balance between the general interests of the community and the protection of the right of property." ${ }^{19}$

Consequently the applicant had suffered a violation of Article 1 of Protocol No 1. Far more significantly the Grand Chamber ruled that the breach in the applicant's case was the product of legislation which created a systemic violation affecting about 100,000 landlords and potentially 900,000 tenants. From our perspective the Grand Chamber's reasoning demonstrates the use of both types of proportionality identified by AraiYakahashi.

The second function being performed by the fair balance principle is to provide a mechanism enabling the Court to determine if the respondent State is subject to an implied positive obligation arising under the Convention. ${ }^{90} \mathrm{~A}$ significant contemporary example is Verein Gegen Tierfabriken Schweiz $v$ Switzerland (no. 2). ${ }^{91}$ As the case title indicates the Grand Chamber was faced with a second complaint by the applicant animal protection association. The association had produced a television commercial campaigning against the battery farming of pigs. The Swiss authorities had refused permission for the advertisement to be broadcast in 1997 and subsequently the association successfully complained to the Court alleging a breach of its right to freedom

${ }^{89}$ Ibid. at para. 225.

90 On the topic of positive obligations and the Convention see, A. Mowbray, The Development of Positive Obligations under the ECHR by the European Court of Human Rights, (Oxford: Hart, 2004).

91 Judgment of 30 June 2009. 
of expression guaranteed by Article $10 . .^{92}$ After the Court's ruling the association had again sought permission for its commercial to be broadcast on Swiss television, but the authorities and the Federal Court refused to authorise the transmission of the advertisement. Thereupon, the association lodged a second application at Strasbourg contending that the continuing ban on its commercial by Switzerland amounted to a new violation of Article 10. During the following year the Committee of Ministers, not having been informed of the Federal Court's decision, completed its supervision of the execution of the Strasbourg Court's judgment. ${ }^{93}$ When the second application reached the Grand Chamber it considered that the central question was:

"...whether, in view of the importance of the execution of its judgments in the Convention system and the applicable principles, the respondent State had a positive obligation to take the necessary measures to allow the television commercial in issue to be broadcast following the Court's finding of a violation of Article 10. In determining whether such an obligation exists, regard must be had to the fair balance that has to be struck between the general interest of the community and the interests of the individual." ${ }^{\prime 94}$

The Grand Chamber found that the advertisement was directed at matters of public interest (consumer health and animal/environmental protection), the Federal Court's rejection of the applicant's domestic legal challenge had been unduly formalistic and Article 10 protected inter alia offensive and shocking ideas so the State's argument that consumers and meat traders might find the advertisement unpleasant did not justify the ban on its transmission. Consequently, a large majority (eleven votes to six) determined that Switzerland had failed to comply with its positive obligation under Article 10.

92 Judgment of 28 June 2001, 34 EHRR 4.

${ }^{93} \operatorname{ResDH}(2003) 125$.

${ }^{94}$ Supra n. 91 at para. 91. 
Verein clearly demonstrated the Court weighing up the applicant's interests against those of the community, as submitted by the respondent State, when determining if the fair balance principle required the latter to undertake positive measures to fulfil the former's Convention rights. It is very rare for the Court to uphold a complaint alleging a breach of a positive obligation under Article 10. ${ }^{95}$ However, given the continued refusal of the Swiss authorities to permit the broadcasting of the advertisement, despite the Court's judgment in the first case, the Grand Chamber evidently believed that this was a situation which required affirmative action by the respondent State.

\section{The identification of competing interests}

From the jurisprudence we can discern a very diverse range of competing interests which the Court has taken cognisance of when applying the fair balance principle. For instance in $B{ }{ }^{96}$ the Court had regard to the protection of the foetus and the mother's physical and mental health when evaluating Italian legislation regulating abortions. The interest of all nations that suspected offenders who flea abroad should be brought to justice balanced against the liberty of such fugitives was at the heart of the Court's analysis in $O O a l a n^{97}$. The liberty of suspected terrorists was also weighed-up against the protection of democratic institutions in $B r o g a n^{98}$. Another aspect of the criminal justice

95 The first successful claim was in Ozgur Gundem $v$ Turkey, Judgment of 16 March 2000, 31 EHRR 49.

${ }^{96}$ Supra n. 25.

97 Supra n. 54.

${ }^{98}$ Supra n.56. 
system was subject to the fair balance analysis in Nikitin ${ }^{99}$ where the Court assessed the general interest of, exceptionally, allowing the re-opening of criminal trials against the opposition of the acquitted defendant. The needs of users and providers of night-time aircraft flights together with the related economic benefits to the whole of the country were balanced against the consequent disturbance to persons affected by the noise of the aeroplanes in Hatton ${ }^{100}$. The objective of public authorities securing "legality" in the leadership and internal affairs of a religious organisation compared with the rights of a break-away group of believers were at the heart of the Court's analysis in Holy Synod ${ }^{101}$. The conflict between an individual civil servant's freedom of political expression and the interests of a democratic State in ensuring that its public service promotes the community interests specified in Article 10(2) (including safeguarding national security) were subjected to the fair balance principle in $\operatorname{Vogt}^{102}$.

From these examples it is possible to conclude that the broad spectrum of competing interests that the Court has had to balance are a product of both the breadth of the rights secured under the Convention and the heterogeneous factual contexts in which applicants contend their rights have been infringed. It is also worth noting that the respondent States have quite often relied upon rather general assertions of community interests, including promoting national economic well-being and controlling the behaviour of civil servants. Such justifications maybe a reflection of the language used

${ }^{99}$ Supra n. 59.

100 Supra n. 64.

${ }^{101}$ Supra n. 68.

102 Supra n. 71. 
by the Convention to elaborate the limitations to qualified Convention rights like Article 8.

\section{Other factors considered by the Court when applying the fair balance principle}

Alongside the interests of the applicant and the community (being advanced by the respondent State), the Court has also taken account of other factors when utilising the fair balance principle. In Broniowski $v$ Poland ${ }^{103}$ the applicant complained that he had suffered a violation of Article 1 of Protocol No 1 due to the failure of the Polish authorities to provide him with the compensation he was entitled to under domestic law in respect of a home his family had been forced to abandon as a consequence of the redrawing of the eastern borders of Poland at the end of the Second World War. The Grand Chamber acknowledged that this application was the first of many raising the same complaint before the Court ${ }^{104}$ and even more individuals were in a similar position. Therefore:

"[t]he vast number of persons involved - nearly 80,000 - and the very substantial value of their claims [over 13 billion Polish zlotys] are certainly factors that must be taken into account in ascertaining whether the requisite "fair balance" was struck." ${ }^{\prime 105}$

In addition the Grand Chamber recognised that the respondent State was seeking to manage the country's reforms in a post-communist society.

"Balancing the rights at stake, as well as the gains and losses of the different persons affected by the process of transforming the State's economy and legal

103 Judgment of 22 June 2004, 40 EHRR 21.

104167 other applications were pending: Ibid. at para 193. Consequently, the Grand Chamber used this case as the first opportunity to process large numbers of applications raising the same systemic defect in a State's legal order under its "pilot judgment" procedure: see Supra n. 41 at pp. 44-45.

105 Supra n. 103 at para. 162. 
system, is an exceptionally difficult exercise. In such circumstances, in the nature of things, a wide margin of appreciation should be accorded to the respondent State.

Nevertheless, the Court would reiterate that that margin, however considerable, is not unlimited and that the exercise of the State's discretion, even in the context of the most complex reform of the State, cannot entail consequences at variance with Convention standards."

Given that the applicant had received less than two percent of the compensation due to him the Court, unanimously, concluded that he had born a disproportionate burden which could not be justified in terms of the general community interest. So even when a broad margin of appreciation had been accorded to the State, because of the scale of the financial and social problems it faced, a fair balance had not been achieved by the domestic legal order.

The Court has also been willing to consider any negative aspects of the conduct of the applicant or the respondent State when applying the fair balance principle. For example, in Beyeler v Italy ${ }^{107}$ the applicant Swiss art dealer/patron had bought a Van Gogh painting in Italy during 1977, through an agent, without informing the authorities that he was the owner as required by national law. In 1983 he notified the authorities of his ownership as a prelude to selling the painting. Five years later the authorities purported to exercise a statutory right to buy the painting at its 1977 value, after the applicant had just agreed to sell it for the much higher price of 8.5 million dollars to a private foundation. The applicant contended that the authorities' action constituted a violation of Article 1 of Protocol No 1 . In applying the fair balance principle the Grand Chamber held that:

"...In the context of the general rule enunciated in the first sentence of the first paragraph of Article 1, ascertaining whether such a balance existed requires an

${ }^{106}$ Ibid. at para 182.

107 Judgment of 5 January 2000, 33 EHRR 52. 
overall examination of the various interests in issue, which may call for an analysis not only of the compensation terms - if the situation is akin to the taking of property (see, for example, the Lithgow and Others [ $v$ UK] judgment [A.102

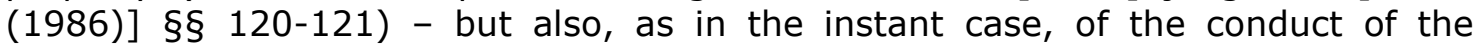
parties to the dispute, including the means employed by the State and their implementation." ${ }^{\prime 108}$

The Grand Chamber found that the applicant had deliberately not informed the authorities of his purchase for six years, in order to avoid the possibility of a statutory purchase by them. Consequently, the Court accepted that there was "some weight" to the respondent State's claim that Beyeler had "not acted openly and honestly". ${ }^{109}$ However, the Grand Chamber was also critical of the State's behaviour in not seeking to purchase the painting for five years:

"That state of affairs allowed the Ministry of Cultural Heritage to acquire the painting in 1988 at well below its market value. Having regard to the conduct of the authorities between December 1983 and November 1988, the Court considers that they derived an unjust enrichment from the uncertainty that existed during that period and to which they had largely contributed. Irrespective of the applicant's nationality, such enrichment is incompatible with the requirement of a "fair balance"."110

Therefore, by sixteen votes to one, the Grand Chamber found a violation as the applicant had been subject to a disproportionate burden by the actions of the Italian authorities. Judge Ferrari Bravo observed in his dissent that he had "serious doubts as to the moral basis for the arguments advanced by both parties to the dispute. ${ }^{111}$ So it is clear that the Grand Chamber was united in its willingness to take account of reprehensible

108 Ibid. at para. 114.

${ }^{109}$ Ibid. at para 116.

${ }^{110}$ Ibid. at para. 121.

${ }^{111}$ Ibid. Dissenting Opinion of Judge Ferrari Bravo. 
conduct by parties to proceedings when assessing whether a fair balance had been achieved between the interests of the applicant and the community.

Another factor which we have regularly encountered the Court taking cognisance of in complaints involving the deprivation of possessions is the payment of adequate compensation. ${ }^{112}$ A contemporary example of this occurred in Kozacioglu $v$ Turkey ${ }^{113}$. The novel issue for the Grand Chamber was whether the fair balance principle required States to compensate owners for the historical value of their properties when these were expropriated. The applicant's building adjoined St. Paul's Well and had been classified as a "cultural asset" by the relevant public authority in 1990. Ten years later the local council expropriated the building, as part of a regeneration scheme. A panel of experts assessed the value of the building, however Turkish law prevented the applicant from being compensated for the historical importance of his building. The Grand Chamber ruled that the safeguarding of a State's cultural heritage was a legitimate aim justifying the expropriation of such possessions under Article 1 of Protocol No 1. Furthermore, States were to be accorded a wide margin of appreciation in legislating when cultural property should be taken into public ownership. However:

"Compensation terms under the relevant domestic legislation are material to the assessment whether the contested measure respects the requisite fair balance... Legitimate objectives of "public interest" may call for less than reimbursement of the full market value of the expropriated property... In the Court's view, the protection of the historical and cultural heritage is one such objective. ${ }^{114}$

As Turkish law prevented any compensation being paid in respect of the historical and cultural value of the applicant's building it was unfair and he had suffered a breach of

${ }^{112}$ See e.g. Jahn supra n. 17 and Beyeler supra n. 107.

113 Judgment of 19 February 2009.

${ }^{114}$ Ibid. at para. 64. 
Article 1. The Grand Chamber, by sixteen votes to one, determined that 75,000 euro pecuniary compensation should be paid. Hence whilst the Court was willing to recognise States' programmes of cultural protection, where possessions are expropriated in the public interest appropriate levels of compensation must be paid.

\section{Conclusions}

From our study we have discovered that the fair balance principle is a judicial creation which the Court declares has its origins in the essence of the Convention where member States undertake to respect the fundamental rights of persons guaranteed by the ECHR whilst also promoting the general interests of their populations. In addition certain Articles, including 8-11 and Article 1 of Protocol No 1, by their qualified structures have provided further justification for the Court applying the principle. However, despite minority opposition, the Grand Chamber has even applied the principle to the unqualified Article $3 .{ }^{115}$ Therefore, the Court's often repeated dictum that the principle is "inherent in the whole of the Convention"116 is an accurate reflection of the constantly evolving jurisprudence.

The principle has been utilised by the Court as a basis for assessing the proportionality of respondent States' interferences with the Convention rights of applicants $^{117}$ and for determining when States are subject to implied positive obligations under the Convention ${ }^{118}$. Thereby demonstrating its value to the Court as a multifunctional tool. When assessing if a fair balance has been achieved in specific cases the

${ }^{115}$ In $N . v$ UK supra n.43.

${ }^{116}$ Supra n. 4.

${ }^{117}$ For example in Hutten-Czapska supra n. 87.

${ }^{118}$ For example in Verein Gegen Tierfabriken Schweiz supra n. 91. 
Court has had to take account of a myriad of competing individual and community interests asserted by applicants and respondent States. Furthermore, the Court has also taken cognisance of additional factors, including the numbers of persons in a similar situation to the applicant ${ }^{119}$ and any reprehensible conduct by either or both of the parties ${ }^{120}$, when applying the principle. Given the difficulties of reconciling these conflicting interests it is perhaps not surprising therefore to sometimes find a powerful dissenting opinion which reaches a diametrically opposite conclusion to that of the majority. ${ }^{121}$

Recognising the challenges faced by the Court when applying the fair balance principle it is now appropriate to return to Judge Terje Wold's objection to the original Court's adoption of the principle. Has the subsequent jurisprudence revealed the principle carrying the Court into the "very middle of the internal political questions of each Member State"? ${ }^{122}$ Well the cases we have examined certainly show the Court applying the principle to governmental decisions involving controversial topics including: controlling pollution ${ }^{123}$, regulating hunting ${ }^{124}$ and supervising the relations between private landowners and their tenants ${ }^{125}$. But the Court has also been willing to accord

${ }^{119}$ For example in Broniowski supra n. 103.

${ }^{120}$ For example in Beyeler supra n. 107.

${ }^{121}$ See e.g. Judge Martens dissent in Brogan supra n.58.

${ }^{122}$ Supra n.12.

${ }^{123}$ For example Hatton supra n. 64.

${ }^{124}$ Chassagnou supra n. 75.

${ }^{125}$ Hutten-Czapska supra n.87. 
deference to national authorities, where the decisions they have taken are complex and subject to differing policy/political approaches, by the use of the margin of appreciation doctrine. Whilst this article is not the place to revisit the arguments for and against the doctrine ${ }^{126}$, our study has encountered the Court according States a range of margins of appreciation. Wide margins were given to decisions, inter alia, over town planning ${ }^{127}$, managing the transformation of a society and its economy from a communist totalitarian system to a free-market democracy ${ }^{128}$ and taking cultural property into public ownership ${ }^{129}$. A narrower "certain" margin was accorded to States when restricting the political activities (during non-working hours) of their civil servants, due to the importance of safeguarding the democratic process. ${ }^{130}$ Whilst the margin was virtually abolished where a State's treatment of a minority group was deficient compared to the international consensus. ${ }^{131}$ Consequently, the Court has deployed the variable margin of appreciation doctrine as a means of altering the intensity of its assessment of the fair balance achieved between community goals and the rights of applicants. Nevertheless, even where a wide margin has been accorded to the governmental authorities this has not prevented the Court from finding breaches of the applicants' Convention rights where

${ }^{126}$ See supra n. 41 at pp. 629-633.

${ }^{127}$ Sporrong supra n. 13.

${ }^{128}$ Broniowski supra n. 103.

${ }^{129}$ Kozacioglu supra n. 113.

${ }^{130}$ Vogt supra n. 71.

${ }^{131}$ Christine Goodwin supra n. 62. 
they have suffered a disproportionate burden. ${ }^{132}$ Such an approach reflects the view of the majority in the Belgian Linguistic case ${ }^{133}$, who first articulated the origins of the fair balance principle, that protection of fundamental human rights necessitates special weight being accorded to it during the application of the principle.

Overall we can conclude that the development and use of the fair balance principle by the Court operates symbiotically with the responsibilities of member States under the Convention. As democratic societies subject to the rule of law ${ }^{134}$ their national authorities need to balance community interests against the basic human rights of individuals. But if the latter believe that their Convention rights have been unjustifiable infringed the Convention, subject to the exhaustion of domestic remedies and the other admissibility criteria ${ }^{135}$, enables the Court to reach a determination. Our study has disclosed the extent and nature of the Court's application of the fair balance principle in making such judgments.

${ }^{132}$ For example in Hutten-Czapska supra n.87.

133 Supra n. 7.

${ }^{134}$ See the preamble to the Convention.

${ }^{135}$ Specified in Article 35 and see supra n. 41 at pp. 19-30. 